\title{
STRUKTUR SEMANTIK KONSEP MANUSIA DALAM AL-QUR'AN
}

\author{
Khairon Nahdiyyin \\ Fakultas Adab, Jurusan Bahasa dan Sastra Arab, Fakultas Adab UIN Sunan Kalijaga Yogyakarta \\ Email: nahdiyyin@yahoo.co.id
}

\begin{abstract}
Semantic analysis on the human structure in The Koran is always interesting to be discussed, especially the one related to the human characterization with its entire symbolical characteristics embedded to the vocabularies applied to them. Human being, in Koran, is termed in many words "Ins, Basyar, Insan, Bani Adam and Naas". This article does not show the relation between human characters, male and female. Instead, it limits the discussion on the human being portrayed by Koran not considering the division of male and female. In this phase, male and female are the same. They are not burdened by unique load for each male and female human being. Instead, they are given characteristics as human being according to the existence. Existentially, it can be said that human being is a group of living creatures among the other God's creatures that is divided into two kinds, jin group and ins group. The ins group is the combination between basyar and insan. The first form of human being is Adam who bring forth the descendant so that all human being born after him is called bani Adam. The descendants of Adam living in the nowadays space and time in called naas. Ins, basyar, insan and bani Adam is a particular concept of human being. Such concept is used by God to remind human being, naas, to always remember to their characteristics that they are ins, basyar, insan and bani Adam. They are bounded to the consequence of the concept.
\end{abstract}

\section{Keywords}

Human Being, The Koran, Semantic

\section{Pendahuluan}

Manusia, di samping Allah dan jin, merupakan salah satu karakter atau tokoh yang ikut terlibat di dalam membentuk peristiwa yang digambarkan dalam al-Qur'an. Keberadaan manusia, sebagaimana jin, adalah sebagai makhluk ciptaan Allah. Sebagai yang diceritakan oleh PenciptaNya, seluk beluk tentang manusia dibeberkan sedemikian rupa sehingga gambaran tentang makhluk seakan-akan terhampar dalam benak siapa saja yang membacanya. Seluk-beluk tentang manusia ini dipaparkan melalui pemakaian sebutan yang Dia berikan kepada makhluk ini. Sebutan yang diberikan kepada makhluk tersebut bukan tanpa maksud tertentu, tetapi sebutan tersebut memiliki nilai semiotik yang tinggi, karena secara umum sebutan tersebut bersifat ikonik bagi acuannya, yaitu manusia.

Pada bingkai yang lebih spesifik, aktor yang terlibat dalam peristiwa yang digambarkan alQur'an melibatkan antar sesama manusia, yaitu laki-laki dan perempuan. Apabila pada tataran hubungan antara Allah dan aktor manusia, laki-laki dan perempuan berada dalam posisi yang sama, maka pada tataran hubungan Allah dan aktor manusia yang terbelah menjadi dua, laki-laki 
dan perempuan, posisi antara keduanya bervariasi. Variasi ini dapat dipahami dari penggunaan sebutan yang dilekatkan pada perempuan. Masing-masing memiliki sebutan yang unik sesuai dengan karakter dan peran yang diberikan.

Tulisan ini mencoba mengetengahkan satu persoalan, yaitu yang terkait dengan ketokohan manusia dengan segala sifat-sifta simbolik yang melekat pada kosa kata yang dikenakan padanya. Karena keterbatasan ruang, tulisan ini tidak menampilkan kaitan antara karakter manusia yang terbelah menjadi dua, laki-laki dan perempuan. Secara sengaja penulis membatasi pada karakter yang dipotret oleh al-Qur'an mengenai manusia secara utuh sebelum terbagi menjadi dua jenis tersebut. Manusia pada tataran ini, baik laki-laki maupun perempuan, sama. Mereka tidak dibebani muatan-muatan yang unik untuk jenis masing-masing melainkan diberi karakter sebagai manusia sesuai dengan tataran eksistensinya.

\section{Manusia dalam al-Qur'an}

Ketika berbicara tentang manusia, al-Qur'an menyebutnya dengan beberapa sebutan di antaranya adalah ins, basyar, insaan, bani Adam dan naas. Masing-masing dari sebutan ini memiliki nuansa makna yang berbeda-beda, karena manusia dilihat dari sudut pandang tertentu meskipun acuannya tetap sama, yaitu mengarah pada ciptaan tertentu dari makhluk Tuhan, dan kata-kata tersebut dalam bahasa Indonesia bermakna sama, yaitu manusia.

Ditinjau dari materi huruf yang membentuk kata-kata tersebut, maksudnya ins, insaan dan naas, hanya kata basyar dan bani Adam yang secara morfologis tidak memiliki kaitan dengan ketiga kata tersebut. Kata ins merupakan kata dasar bagi kata insaan, dan kata naas, yang menurut satu pendapat dianggap berasal dari kata unaas yang kemudian hamzah-nya dibuang, merupakan bentuk jamak dari kata insaan (Ibn al-Mandzur, t.t.:307). Secara umum, makna dasar kata ins dan derivasinya berkisar di antara 2 makna yaitu pertama lawan dari kata liar, yang berarti jinak, dan kedua memperlihatkan atau diperlihatkan, ditampakkan (Ibn al-Manzdur, t.t.: 313).

Meskipun hanya tiga kata tersebut yang memiliki kaitan morfologis antara satu kata dengan yang lainnya, namun secara semantik kata basyar dan bani Adam, ditinjau dari makna yang dikandungnya memiliki makna yang sama, yaitu berkisar pada aspek ketampakan makhluk tertentu dari ciptaan Tuhan, dengan segala konsekwensi yang timbul dari makna ketampakan tersebut seperti mengalami perpindahan dan perubahan sebagaimana yang ditunjukkan pada makna kata basyar dan bani Adam. Bahkan secara khusus kata basyar menunjukkan aspek materiil dari manusia yang pertama kali dapat dilihat, yaitu kulit yang merupakan bagian terluar dari wujud manusia. Makna ini akan menjadi tampak jelas apabila kita memperhatikan makna tersebut secara kebahasaan sekaligus pemakaian al-Qur'an terhadap kata-kata tersebut.

\section{Pertama, Ins}

Kata ini dalam al-Qur'an disebutkan dalam 17 surat secara bersama-sama dengan kata jinn atau jaann (Binti al-Syathi', t.t.:14). Kadang-kadang kata ins disebutkan mendahului kata jin dan demikian pula sebaliknya. Namun kata jinn lebih banyak mendahului kata ins. Tampaknya hal ini menunjukkan urut-urutan keberadaan yang berawal dari yang tidak terlihat ke yang tampak. Di samping itu, didahulukannya jinn dari ins juga dapat didasarkan pada urut-urutan penciptaan sebagaimana yang ditunjukkan dalam surat al-Hijr ayat 27, dan juga dapat disimpulkan dari sebutan khalifah dalam cerita Adam. Kata khalifah dalam sebuah riwayat lebih tepat diartikan dengan makna "mukhallaf", maksudnya makhluk yang diciptakan belakangan. 
Kata yang sama dengan ins adalah insiyy dengan bentuk jamaknya "'anaasiya". Akan tetapi, kata ini dalam pemakaian al-Qur'an tidak pernah muncul secara bersama dengan kata jinn. Baik bentuk tunggal maupun jamaknya hanya dapat ditemukan sekali. Bentuk tunggal terdapat dalam surat Maryam ayat 26, sementara bentuk jamak terdapat dalam surat al-Furqa>n. Hubungan antara kata "ins" dengan "insiyy" sama dengan hubungan antara kata "`arab" dengan "'arabiyy" dan semacamnya; yang pertama umum dan menyeluruh, sementara yang kedua khusus dan terbatas.

Kata ins mendahului kata jin pada konteks pembicaraan tentang kesucian bidadari (QS. alRahman: 39, 56 dan 74), anggapan jin tentang makhluk manusia dan jin (QS. al-Jinn: 5), dan sikap permusuhan manusia dan jin terhadap setiap nabi (QS. al-An'am: 112).

Ditinjau dari pemakaiannya yang disebutkan secara bersama-sama dengan kata jinn, kata ins mengacu pada makna jinak, yang berarti dapat dilihat dan ditangkap karena memang diperlihatkan, karena makna kata "jinn" secara bahasa berarti samar, tertutup dan tidak dapat ditangkap (Binti al-Syathi', t.t.: 313). Tentunya, ini dipandang dari sudut dunia manusia. Dari makna bahasa ini dapat ditarik kesimpulan bahwa sebenarnya makhluk Tuhan ada dua, yaitu bangsa ins, bangsa makhluk Tuhan yang diperlihatkan sehingga terlihat, dan yang tertutup sehingga tidak terlihat (oleh manusia), yaitu jinn.

Kata ins disebutkan secara bersama-sama dengan kata jinn atau jânn, ini memiliki makna bahwa keduanya dalam banyak hal memiliki kesamaan. Di antara kesamaan yang disebutkan dalam alQur'an adalah bahwa mereka sama-sama menjadi makhluk yang diciptakan Tuhan untuk menyembah-Nya (QS. Al-Dzariyaat: 56), kepada masing-masing di antara keduanya sama-sama dikirimkan utusan-utusan dari kalangan mereka sendiri (QS. al-An'am: 13); sama-sama diberi potensi kemampuan untuk menembus melampaui batas dunia masing-masing ke dunia lain yang lebih tinggi (QS. al-Rahman: 39); sama-sama ditantang untuk membuat yang semisal dengan alQur'an (QS. al-'Isra': 88); sama-sama dimungkinkan untuk menjadi musuh bagi nabi (QS. alAn'am: 112); sama-sama dimungkinkan untuk berhubungan dan saling mempengaruhi baik antar keduanya atau antar masing-masing, secara negatip terutama jin kepada manusia (QS. al-An'am: 112, 128; QS. al-A'raaf: 38; QS. al-Jinn: 6), dan sama-sama dimungkinkan mereka mendapatkan siksa sebagai akibat dari kelalaian mereka berdua di dalam menunaikan tugas utamanya sebagai hamba yang mendapatkan takliif yang harus ditunaikan (QS. al-A'raaf: 38, 179; QS. Fushshilat: 29; QS. al-Jinn: 5).

Di samping bahwa makhluk Tuhan itu ada dua jenis, yang terlihat dan tidak tampak sebagaimana disebutkan di atas, penyebutan dua jenis makhluk ini dalam al-Qur'an lebih ditekankan pada aspek adanya hubungan antara keduanya, hubungan saling mempengaruhi satu sama lain dengan tekanan utamanya bahwa jin sering dianggap sebagai yang dapat menyesatkan manusia, dan manusia sendiri menjadikan jin sebagai tempat perlindungan, subyek yang dimintai pertolongan (QS. al-Jinn: 6; QS. al-A'raaf : 38, dan QS. al- An'am: 112).

Gradasi turunnya ayat-ayat Al-Qur'an yang memuat kata-kata ins dan jinn, yang semuanya terdapat dalam surat makkiyah, menunjukkan bahwa jin dan manusia dimungkinkan memiliki kemampuan tertentu untuk menguasai bumi dan langit melalui perangkat-perangkat penguasaan, namun demikian kemampuan itu harus dalam kerangka menyembah Tuhan. Dalam kenyataannya di antara manusia dan jin justru saling bahu-membahu untuk mengabaikan hal itu, sehingga mereka menerima akibat hukuman, padahal mereka telah diberi peringatan melalui para rasul yang didatangkan kepada mereka dan dari kalangan mereka sendiri. 


\section{Kedua, Basyar}

Kata ini muncul baik dalam surat-surat makkiyah maupun madaniyyah. Surat-surat makkiyah yang memuat kata ini, sekitar 20 surat, dalam kaitannya dengan penciptaan manusia, kemanusiaan para nabi dan rasul dan ketidak-mungkinan basyar untuk berkomunikasi secara langsung dengan Allah. Sementara itu dalam surat madaniyyah kata ini muncul dalam tiga surat, yaitu QS. al-Taghaabun: 6, QS. Ali Imran: 47 dan 79, dan QS. al-Maidah: 18. Dalam surat-surat tersebut kata ini berkaitan dengan ke-basyar-an para rasul, orang-orang Yahudi dan Nasrani, serta ketidakmungkinan basyar, dalam konteks Nabi Isa, untuk mengaku sebagai Tuhan setelah ia diberi al-Kitab, Hikmah dan kenabian.

Yang ditunjuk oleh kata ini dalam al-Qur'an secara spesifik adalah apa yang terlihat dan tampil di permukaan dari wujud manusia, apakah itu secara fisik-biologis ataupun tindakan-tindakan aktual dari fisik manusia. Makna ini ditampilkan melalui ungkapan basyar yang menunjuk pada makna kulit. Apabila kata ins di atas juga bermakna makhluk yang diperlihatkan, maka yang dimaksudkan di sini adalah bagian-bagian dari makhluk tersebut yang diperlihat, yaitu anggota tubuh dan fungsi-fungsinya. Dengan demikian kata basyar dapat dianggap sebagai penjelasan terhadap makna ins yang bersifat umum, atau kata tersebut merupakan bentuk aktualisasi dari makna ins yang sangat luas yang mencakup semua makhluk yang ditampakkan. Oleh karena itu, menurut Abd Shabuur Syahin (2001:76) kata basyar bermakna asal "yang paling menonjol di antara semua makhluk Tuhan". Makna ini sejalan dengan makna dasar dari kata tersebut ditinjau dari makna bahasanya, yaitu kulit tempat di mana rambut manusia dapat tumbuh, kulit sebagai simbol dari bagian paling luar dari fisik manusia (Ibn al-Mandzur, t.t.: 125). Demikian pula halnya dengan tindakan-tindakan fisik manusia. Yang ditonjolkan dalam kata ini adalah kemanusiaan manusia yang terdiri dari kulit, daging dan tulang serta konsekwensi yang muncul dari fisik kemanusiaan ini, seperti makan, minum, pergi ke pasar dan lain-lain tindakan yang menjadi tindakan umum kemanusiaan.

Makna kata basyar yang semacam ini tampaknya berkaitan erat dengan asal-usul materi yang dipergunakan untuk menciptakan mereka, yaitu "thiin" yang mengandung unsur debu dengan air (Syahin, 2001:77). Di samping itu kata basyar juga dipergunakan dalam kaitannya dengan penciptaan. Secara umum penciptaan manusia sebagai basyar dikaitkan dengan elemen-elemen fisik yang kasar, selain air, seperti debu, tanah kemudian tanah liat yang kering dan keras (QS. al-Hijr: 28, 33; QS. al-Ruum: 20; QS. al-Furqaan: 54 dan QS. Shaad: 71).

Oleh karena yang ditonjolkan pada kata basyar adalah pada aspek ini, banyak ayat al-Qur'an yang berkaitan dengan kata basyar, dan ayat-ayat tersebut mengindikasikan bahwa manusia dalam pengertian basyar ini tidak memiliki kualitas kemanusiaan yang menunjukkan kelebihan manusia yang satu atas yang lainnya. Sebagai basyar manusia hanyalah kumpulan dari organorgan tubuh yang memiliki fungsi fisiologis semata dan memiliki kaitan dengan tindakantindakan yang memerlukan topangan organ-organ fisik.

Oleh karena demikian, tidak mengherankan, ketika aspek ini yang ditekankan, apabila para nabipun dipandang sama dengan manusia lainnya. Mereka memiliki anggota tubuh yang sama sebagaimana anggota tubuh manusia lainnya. Sebagai konsekwensinya, sebagian masyarakat ketika diajak untuk mengikuti nabi, menolak untuk mentaati atau mempercayai nabi ataupun rasul karena mereka melihat nabi atau rasul pada aspek ini sama saja dengan manusia lainnya. Tidak ada perbedaan antara manusia biasa dengan mereka yang mengaku sebagai nabi atau rasul (QS. al-Maidah: 18; QS. al-An'am: 91; QS. Ibrahim: 10; QS. al-Nahl: 103; QS. al-Anbiya': 3; 
QS. al-Mukminun: 24, 33, 34; QS. al-Syua'ra': 153, 186; QS. Yaasiin: 36; QS. al-Taghaabun: 6; QS. al-Mudatstsir: 25; QS. Huud: 27; QS. Yusuf: 31; QS. al-Isra': 94; QS. al-Qamar: 34). Bahkan ketika dikatakan seorang malaikat, sebagaimana dalam surat Maryam ayat 17, merubah wujudnya sebagai manusia dinyatakan dengan kata basyar. Ini berarti bahwa wujud malaikat tersebut dilihat dari organ-organ fisik manusia.

Pada aspek ini semua manusia dalam berbagai tingkatan sosial-budaya adalah sama, tidak ada yang melebihi satu sama lainnya. Oleh karenanya, pada saat yang sama, para Rasul dan Nabi juga menekankan aspek ini ketika mereka menyebarkan dakwahnya. Mereka adalah manusia biasa sebagaimana manusia lainnya yang terdiri dari berbagai organ tubuh yang sama, hanya saja mereka adalah manusia yang diberi wahyu, yang diutus oleh Tuhan untuk menyampaikan tauhid (lihat QS. Ibrahim: 11; QS. al-Kahfi: 110; QS. Fushshilat: 6 dan QS. al-Isra': 9).

\section{Ketiga, Insaan}

Kata ini dapat ditemukan dalam 45 surat dengan rincian 41 surat Makkiyah dan 4 surat Madiniyah. Dalam empat surat yang terakhir ini manusia digambarkan sebagai makhluk yang diciptakan dalam keadaan lemah (QS. al-Nisa': 28) karena manusia menjadi obyek yang mudah digoda setan (QS. al-Hasyr: 16) sehingga ia lupa akan jati dirinya sebagai makhluk Tuhan (QS. al-Hajj: 66). Di samping itu juga dinyatakan keberanian manusia untuk memikul amanat yang enggan diterima oleh langit dan bumi karena khawatir tidak sanggup menjalankannya (QS. alAhzaab: 72). Sementara itu surat-surat Makkiyah lebih menekankan pada aspek penciptaan manusia, dari apa dan bagaimana manusia diciptakan dengan segala kekurangan dan kelebihan watak yang melekat pada dirinya, dan kecenderungan manusia untuk mengingkari nikmatnikmat yang telah diberikan kepadanya. Manusia melupakan watak dasar dirinya sendiri.

Apabila dua kata sebelumnya, ins dan basyar, tidak terkait dengan sifat-sifat dan atribut psikologis dan kognitif dari manusia, maka kata insaan justru memperlihat kualitas dari manusia. Kata ini tidak menekankan pada aspek kemanusiaan secara fisik, seperti yang ditunjukkan pada kata basyar, atau aspek keberadaannya di dunia secara konkrit sebagaimana yang ditunjukkan dalam kata ins. Tetapi, kata ini lebih menekankan pada aspek psikologis manusia yang dapat berpikir dan merasakan apa yang dialaminya. Namun demikian harus dipahami bahwa insaan tidak ada tanpa ada basyar, karena sifat insaan senantiasa melekat pada sifat basyariyah manusia. Basyar merupakan wujud materi, sementara insaan merupakan eksiden bagi materi tersebut.

Apabila diperhatikan ayat-ayat al-Qur'an yang menyebutkan kata insaan, akan dapat diambil kesimpulan bahwa kata ini berkaitan, pertama, dengan watak manusia yang memiliki hubungan dengan sikap-sikap negatip dari manusia, kedua dengan asal usul penciptaannya, ketiga dengan pengajaran yang diberikan Allah, dan keempat dengan beban yang diberikan kepadanya.

Di antara sifat-sifat yang banyak disebutkan dalam al-Qur'an berkaitan dengan watak manusia adalah bahwa manusia sering melupakan Tuhannya ketika sedang dalam keadaan senang, padahal ketika sedang susah mereka senantiasa membutuhkan dan berdoa kepada Tuhan (QS. Hud: 9; QS. Yunus: 12; QS. al-Isra': 67, 83, 100; QS. Ibrahim: 34; QS. al-Zumar: 8, 49; QS. Fushshilat: 51; QS. al-Syuuraa: 48). Berangkat dari watak ini kata insaan sering dikaitkan dengan ungkapan seperti manusia cepat putus asa, tidak mau terima kasih, sangat dzalim, pelit, keluh kesah dan semacamnya. 
Kata insaan juga dikaitkan dengan asal-usul penciptaannya. Namun demikian, asal usul penciptaan manusia di sini sedikit agak berbeda dengan asal-usul yang disebutkan dalam kaitannya dengan kata basyar. Meskipun juga dikaitkan dengan unsur-unsur sebagaimana yang disebutkan dalam basyar, seperti tanah yang liat dan debu, kata insaan dikaitkan paling sering dengan kata nuthfah (QS. al-Insaan: 2; QS. Yaasiin: 77; QS. al-Nahl: 4). Tampaknya kata basyar dalam fase penciptaannya lebih terkait dengan tanah, sementara kata insaan lebih berkaitan dengan nuthfah. Apabila tanah dianggap elemen yang paling mendasar dari elemen-elemen penciptaan manusia dan elemen ini bersifat kasar atau mentah sehingga dapat dijadikan sebagai simbol bagi keberadaan fisik manusia, maka nuthfah di sini dapat dianggap sebagai perkembangan lanjut dari perubahan elemen mendasar tersebut menjadi elemen yang lebih halus dan lunak. Apabila ini benar, maka kaitan tersebut sejalan dengan pemakaian istilah basyar dan insaan. Maksudnya, ada kesejajaran perkembangan antara istilah tersebut dengan elemen-elemen penciptaannya.

Surat yang pertama diturunkan menyatakan bahwa manusia mendapat pengajaran dari Allah. Dia mengajarkan kepada manusia apa yang belum diketahui manusia. Dalam surat al-Baqarah berkaitan dengan cerita Adam pengajaran tersebut berkaitan dengan pemberitahuan kepada Adam nama-nama atau sebutan-sebutan, termasuk dalam pengertian mengajarkan di sini adalah pemberian takliif kepada insaan. Takliif kepada manusia, yang disimbolkan untuk pertama kalinya melalui Adam, terdiri dari dua hal yang kontradiksi yang salah satunya harus dijalankan sementara yang lainnya harus dihindari. Manusia dalam konsep ini, insaan, adalah makhluk yang hidup dalam dua daya tarik yang saling bertentangan, karena manusia ini memiliki semua perangkat yang dapat mengarahkannya untuk membedakan keduanya yang bertentangan sesuai dengan akalnya. Namun demikian konsep insaan dalam al-Qur'an cenderung negatip dalam pengertian manusia dalam konsep ini cenderung kalah, atau mudah mengikuti pada, dengan tuntutan-tuntutan lingkungannya yang sering menjerumuskan pada sisi negatip yang justru menjadi larangan untuk dilakukan. Oleh karena itu dikatakan bahwa manusia diciptakan dalam keadaan cenderung menuruti fakta-fakta meterinya sehingga melupakan hakekat keberadaannya (QS. al-Nisa': 28.).

Beban yang diberikan kepada insaan lebih banyak diarahkan agar, pertama-tama, manusia tidak menyimpang dari jalan Allah dengan jalan bertakwa, dan kedua bersikap baik kepada orang tua yang melahirkannya. Sikap-sikap baik kepada orang tua yang disebutkan al-Qur'an di antaranya berterima kasih kepadanya dan mendoakannya. insaan harus berbuat baik kepada kedua orang tua sekalipun insaan tidak berkenan ketika keduanya mengajak untuk bersikap syirik.

\section{Keempat, Bani Adam}

Kata Bani Adam menurut bahasanya adalah keturunan atau anak-cucu Adam, karena Adam dianggap sebagai insaan pertama yang muncul di bumi. Kata Adam secara bahasa bisa berarti permukaan, bagian dalam dari kulit dan bagian yang menjadikan sesuatu dapat dikenali. Dari Adam inilah manusia mulai dikenali dalam pentas kehidupan di permukaan bumi. Kata ini dalam al-Qur'an disebutkan sekitar tujuh kali. Adam merupakan wujud awal dari konsep basyar yang telah menjadi insaan. Dia dan pasangannya merupakan insaan pertama yang dimunculkan dalam pentas kehidupan dunia. Oleh karena itu, ungkapan bani Adam dalam al-Qur'an mengacu pada keseluruhan anak manusia semenjak dari keturunan awal Adam hingga akhir zaman.

Al-Qur'an mempergunakan istilah ini, terutama dalam rangka mengingatkan asal-usulnya yang berkaitan dengan cerita Adam. Mereka harus berkaca pada pengalaman Adam yang pernah 
dijerumuskan oleh setan ke dalam tindakan yang dilarang Tuhan (QS. al-A'raaf: 27). Oleh karena itu, ungkapan bani Adam lebih menekankan pada peringatan terhadap manusia agar memegang nikmat yang telah diberikan kepada Allah, apakah nikmat itu berupa pemberian kemulyaan, penghidupan di darat dan laut, pemberian rizki ataupun kedudukan di atas makhluk lainnya (QS. al-Isra': 70); ikatan janji primordial untuk tidak menyembah setan karena telah bersaksi bahwa Allah adalah Tuhannya (QS. Yaasiin: 60, dan QS. al-A'raaf: 172), yang telah memberikan pakaian takwa yang harus mereka pergunakan setiap kali mereka menuju ke tempat sujud, dan itu bumi itu sendiri (QS. al-A'raaf: 31).

\section{Kelima, Naas}

Al-Qur'an paling banyak menggunakan kata ini dibandingkan dengan kata-kata yang disebut di atas meskipun sama-sama mengacu pada manusia. Kemunculan kata tersebut dalam al-Qur'an mencapai 240 kali. Yang paling banyak muncul kata tersebut dalam bentuk definit, dengan memakai partikel al. banyaknya pemakaian kata naas dalam al-Qur'an berkaitan dengan acuan yang ditunjukkan oleh kata ini.

Pengamatan terhadap pemakaian kata naas dalam al-Qur'an memperlihatkan bahwa al-Qur'an menggunakannya dalam pengertian manusia dalam aktualnya di muka bumi dengan segala sepak terjangnya, apakah negatip ataupun positip. Manusia ini adalah manusia yang berada dalam ruang dan waktu yang aktual. Karena mengacu pada wujud manusia secara faktual dalam kehidupan dunia ini, kepada naas inilah titah Tuhan sering diarahkan, seperti titah untuk menyembah (QS. al-Baqarah: 21), memakan makanan yang halal dan bagus (QS. al-Baqarah: 168), untuk bertakwa (QS. al-Nisa': 1) dan lain sebagainya.

Oleh karena demikian, kata naas apabila disapa secara langsung pada umumnya diganti dengan kata ganti orang kedua, ka, kum, dan lain sebagiannya.

Pemakaian al-Qur'an yang semacam ini terhadap kata naas tampak sejalan dengan makna kata tersebut apabila ditinjau dari sisi bahasa. Di samping dikatakan memiliki makna seperti ins, sebagaimana diterangkan di atas, kata naas dari sudut lain dapat dianggap berasal dari kata naasa-yanuusu, yang berarti bergerak ke sana kemari. Manusia dikatakan dengan sebutan nâs karena manusia bergerak dan mengalami perubahan dan berbeda-beda serta berubah-ubah (Ibn al-Mandzur, t.t.: 131). Barangkali makna inilah yang dapat ditangkap dari firman Allah dalam surat Yunus ayat 19.

Dengan demikian, apabila kata-kata yang disebut sebelumnya lebih mengacu pada konsep tentang manusia, kata naas lebih menunjuk pada sepak terjang manusia yang merupakan realisasi aktual dari konsep tersebut di atas, ins dalam bentuk basyar dan insaan serta bani Adam.

Tampak jelas bahwa semua kata-kata tersebut memperlihat makna ketampakan makhluk tertentu dari ciptaan Tuhan.

\section{Penutup}

Dari paparan tentang sebutan terhadap makhluk manusia sebagaimana diuraikan di atas dapat disimpulkan bahwa manusia dalam penciptaannya mengalami tahapan, dan demikian pula dengan eksistensinya. Berkaitan dengan penciptaannya wujud manusia adalah wujud yang terlihat, ins. Sisi ketampakan makhluk manusia, pada dasarnya, karena ia berada dalam bentuk basyar yang hanya terdiri dari organ-organ tubuh, kemudian manusia memiliki kemampuan kognitif dan kualitas-kualitas tertentu yang menjadi karakternya sehingga ia menjadi insaan. 
Tahapan penciptaan ini dapat berkaitan, pertama, dengan asal mula penciptaannya sebagaimana yang dapat dipahami dari penjelasan di atas, dan juga dapat dikaitkan, kedua, dengan perkembangan wujud manusia setelah dilahirkan. Ketika masih bayi yang tampak pada manusia adalah badannya dan segala gerak-gerik yang berkaitan dengan fisiknya, dan setelah mengalami perkembangan bayi mulai mendapat unsur-unsur yang memungkinkannya mendapatkan kesadaran kognitif sehingga ia berhak menyandang nama insa $>n$ karena perangkat-perangkat kognitif mulai dapat bekerja, setelah dia dapat bergabung dengan insaan-insaan lainnya dalam suatu kominitas manusia, naas.

Secara eksistensial dapat dikatakan bahwa manusia merupakan kelompok makhluk hidup yang ditampakkan di antara makhluk Tuhan yang terbagi ke dalam dua jenis, yaitu kelompok jin dan kelompok ins. Kelompok ins berupa gabungan antara wujud basyar dengan insaan. Wujud pertama dari manusia ini adalah Adam yang melahirkan keturunan-keturunannya sehingga semua manusia yang lahir setelahnya disebut bani Adam. Anak keturunan Adam yang ada dalam ruang dan waktu inilah yang kemudian disebut dengan naas. Ins, basyar, insaan dan bani Adam merupakan konsep tertentu tentang manusia. Konsep inilah yang dipergunakan oleh Tuhan untuk mengingatkan manusia, naas, agar senantiasa ingat akan wataknya, bahwa mereka adalah ins, basyar, insaan dan bani Adam. Mereka terikat dengan segala konsekwensi dari konsep tersebut.

Patut disebutkan di sini, bahwa sebutan ins, basyar, insaan dan bani Adam sering dipergunakan dalam al-Qur'an sebagai peragkat untuk mengingatkan watak dan makna sebenarnya dari eksistensi manusia. Oleh karena itu ketika kata-kata tersebut diutarakan dalam al-Qur'an penyebutan tersebut dalam rangka mengingatkan kembali, flash back, kepada masa lalu manusia. Seolah-olah manusia dalam kenyataannya, naas, memiliki pengalaman yang sama berkaitan dengan wataknya. Oleh karena itu apabila sebutan-sebutan tentang manusia ini diletakkan dalam ruang dan waktu dan dikaitkan dengan proses penciptaannya, maka akan dapat digambarkan, bahwa kata naas mengambil posisi pada manusia kini, sementara kata-kata lainnya, ins, basyar, insaan dan bani Adam,

dapat diletakkan pada posisi masa lalu.

Meskipun demikian, harus diingat bahwa meskipun sebutan-sebutan tersebut apabila dikaitkan dengan proses penciptaannya, di satu sisi, dan di sisi lain, sebutan-sebutan tersebut diletakkan dalam ruang dan waktu, dapat digambarkan seperti itu, namun manusia dalam wujud aktualnya yang terepresentasikan dalam kata naas, pada saat yang sama terkandung dalam dirinya unsurunsur basyar, insaan dan bani Adam.

Sementara itu tahapan keberadaan manusia dapat digambarkan dalam diagram berikut: 
Yang penting untuk disebutkan di sini, bahwa sampai pada batas perkembangan ini tidak ada pembedaan antara manusia. Manusia pada tahap ini tidak memiliki perbedaan jenis kelamin. Semua manusia, sebagai ins, basyar, insan, bani Adam dan naas adalah sama. Meskipun dapat diasumsikan bahwa pada masing-masing dari sebutan tersebut sudah ada perbedaan jenis kelamin, terutama setelah proses penciptaan terjadi, dan perbedaan-perbedaan lainnya karena faktor sosio-kultural dalam hal ini ketika manusia pada tataran naas, akan tetapi perbedaan ini tidak menjadi fokus utama atau bahkan diabaikan sama sekali dalam konteks sebutan atau katakata tersebut. Bahkan dalam tataran naas sendiri tidak ditunjukkan adanya perbedaan.

\section{DAFTAR PUSTAKA}

Abd al-Baaqi', Muhammad Fu'ad. 1981. Al-Mu'jam al-Mufahras li Alfaadz al-Qur'an alKariim. Beirut: Daar al-Fikr.

Abu Jaib, Sa'diy. 1993. al-Qaamuas al-Fiqhiy lughatan wa ishthilaahan. Damaskus: Daar alFikr.

Abu Zaid, Nasr Hamid. 1999 Dawa'ir al-Khauf, Qira'ah fii Khithaab al-Mar'ah. Beirut: alMarkaz al-Tsaqaafiy al-Arabiy.

1999, Manhaj al-Diraasah al-Adabiyyah li al-Qur'an; al-Juzuur wa Aafaaq alMustaqbal, dalam al-Nahj tahun 15/1999. Suriah: Markaz al-Abhaas wa al-Diraasaat alIsyiraakiyyah fi al-'aalam al-Arabiy.

Al-Askariy. Tanpa tahun. Al-Lum'ah min al-Furuuq. Surabaya: al-Maktabah al-Tsaqaafiyyah.

Alasuutari, Pertti. 2000. Researching Culture, Qualitative Methode and Cultural Studies. London: Sage Publications.

Arkoun, Mohammed. 1992. Lectures du Coran, Paris: Maisonneuve \& Larose.

Binti al-Syathi', Aisyah. Tanpa tahun. Al-I'jaaz al-Bayaaniy li al-Qur'an. Mesir: Daar al-Ma'arif. .. Tanpa tahun. Maqaal fii al-Insaan: Diraasah Qur'aniyyah. Mesir: Daar al-Ma'arif.

Ibn al-Mandzur. Tanpa tahun, Lisaan al-Arab.. Mesir: Bulaaq.

Ibn Katsir. Tanpa tahun. Tafsiir al-Qur'an al-'adziim. Tanpa kota: Syirkah Nuur Asia

Jespersen, Otto. 1929. The Philosophy of Grammar. London: George Allen \& Unwin.

Khuli, Amin. 1995. "Manaahij Tajdiid fii al-Nahwi wa al-Balaghah wa al-Tafsiir wa al-Adab" dalam al-A'maal al-Kaamilah, Vol. X. Mesir: al-Hay'ah al-Mishriyyah al-Ammah li alKitaab. 
Madsen, Deboral L., 2000. Feminist Theory and Literary Practice. London: Pluto Press.

Mahmud, Zaki Najib, 1973, Tajdiid al-Fikr al-Arabiy, Beirut: Daar al-Syuruuq.

Ma'luf, Louis. 1986. Al-Munjid fii al-Lughah. Beirut: Daar al-Masyriq.

Musa, Hasan Muhammad. 1966. Qaamuus Qur'aniy. Al-Iskandariyah: Khalil Ibrahim.

Naysaabuuriy. 1968. 'Asbaab al-Nuzuul. Kairo: Musthafa al-Baabiy al-Halabiy.

Scholes, Robert. 1982. Semiotics and Interpretation. USA: Yale University .Press.

Segers, Rien T., 1978. Studies in Semiotics, the Evaluation of Literary Texys. Leiden: The Peter De Ridder Press.

Sha'alibiy, Abu Manshuur. 1972. Fiqh al-Lughah wa Sirr al-'Arabiyyah. (ed. Musthafa alSaqaet. All). Kairo: Musthafa al-Baabiy al-Halabiy.

Shahrur, Muhammad. 2000. Nahw 'Ushuul Jadiidah li al-Fiqh al-'Islaamiy, Fiqh al-Mar'ah. Damaskus: al-Ahaaliy

Stowasser, Barbara Freyer. 1994. Women in the Qur'an, Traditions, and Interpretation. New York: Oxford University Press.

Syaahin, Abd Shabuur. 2001. Abii Adam Qishshah al-Khaliiqah bain al-Usthuurah wa alHaqiiqah. Kairo: Akhbaar al-Yawm.

Umar, Nasaruddin, 1999, Argumen Kesetaraan Gender, Perspektif al-Qur'an, Paramadina, Jakarta

Wadud, Aminah. 1999. Qur'an and Women. New York: Oxford University Press,.

Zarkasyi. 1971. Al-Burhaan fi 'Uluum al-Qur'an. Mesir: Isa al-Baabiy al-Halabiy. 